\title{
Household uses of the banana plant in eastern Democratic Republic of Congo
}

\author{
Kamira $\mathrm{M}^{1}$, Sivirihauma $\mathrm{C}^{2}$, Ntamwira $\mathrm{J}^{1}$, Ocimati $\mathrm{W}^{*}$, Katungu $\mathrm{MG}^{2}$, Bigabwa $\mathrm{JB}^{4}$, Vutseme $\mathrm{L}^{2}$ and \\ Blomme $\mathbf{G}^{5}$
}

\author{
1Bioversity International, South Kivu, Democratic Republic of Congo mkamira2@yahoo.fr; ingjules2007@yahoo.fr \\ 2Université Catholique du Graben, Butembo, North Kivu, Democratic Republic of Congo c.sivirihauma@gmail.com; \\ gracemukatakamba@yahoo.fr; vutseme12@yahoo.fr \\ 3Bioversity International, Uganda w.ocimati@cgiar.org; \\ ${ }^{4}$ Université Catholique de Bukavu, South Kivu, Democratic Republic of Congo \\ 5Bioversity International, Addis Ababa, P.O. Box 5689, Addis Ababa, Ethiopia g.blomme@cgiar.org \\ *Corresponding author (w.ocimati@cgiar.org)
}

Original submitted in on 30 th April 2015. Published online at www. m. elewa.org on 30 th November 2015

http://dx.doi.org/10.4314/jab.v95i1.1

\begin{abstract}
Objective: Banana is ranked first among staple crops in the eastern Democratic Republic of Congo (DR Congo). Depending on the agro-ecological conditions, cultivars grown, cultural and socio-economic factors, the use of other banana plant parts other than the fruit pulp, has been widely reported. This has not been documented in this region. This study examined the other household uses of banana in North and South Kivu provinces, eastern DR Congo.

Methodology and results: This study was conducted through surveys covering 200 randomly sampled households (with at least 50 banana mats), each in North and South Kivu in the years 2011. Data were collected on the use of different banana parts, other than the fruit pulp, using a structured questionnaire. All the banana parts were found to be useful, though with varying levels of importance. Commonly used parts included the leaves (green/dry), pseudostem and the peels. The corms/rhizomes were the least used parts. The most prevalent uses across plant parts included use for mulch and compost, feed for livestock, construction materials, ropes for tethering small ruminants and play items. A small fraction of the households used male buds for food, feed and medicine. Other uses included extraction of fibre, arts and crafts and use as medicine. Conclusion and application of findings: Culinary and medicinal attributes, use for art and crafts however, look to be underexploited and yet could be of great benefit to resource constrained communities. An in-depth study is recommended especially to verify and understand the culinary and medicinal attributes reported for the different plant parts in the region. Use of the male bud as a vegetable was also reported and could be promoted among communities in the region. The nutrient value of the pseudostem is high and could be promoted as animal feed in this highly populated region to enable zero grazing of small ruminants.
\end{abstract}

Key words: Culinary, medicinal attributes, tethering 


\section{INTRODUCTION}

The Great Lakes region covering parts of Uganda, Rwanda, Burundi, Tanzania, Kenya and the Democratic Republic of Congo (DR Congo) is the largest producer and consumer of banana in Africa (Smales, 2006). Banana is a very important crop in the DR Congo where it is traditionally grown in mixed cropping systems. It is an important source of food and income (Bakelana et al., 2000), with $70 \%$ of the production consumed on farm (Vangu, 2005). Banana is ranked first among staple crops in South Kivu and North Kivu as far as area and production is concerned. It covers 1.35 million hectares and the annual production is 3.7 million tonnes (Ministry of Agriculture, 2002). Banana is a giant perennial tropical rhizomatous plant belonging to the Musaceae family. Tightly packed overlapping leaf sheaths form the pseudostem and the true stem is the underground tuberous rhizome (Robinson \& Galan, 2010). During the reproductive stage, the true stem extends upwards, forming the inflorescence stalk and leading to the emergence of the inflorescence at the top of the plant. The pseudostem grows to a height of 2 to $8 \mathrm{~m}$ depending on the cultivar and the biophysical conditions. The leaves are up to $2.7 \mathrm{~m}$ long and $0.61 \mathrm{~m}$ wide (PTRI, 2005). Most of the banana plants produce $30-40$ leaves in a lifetime (Pillay \& Tripathi, 2007) but as older leaves are pushed outwards, they eventually die leaving $5-15$ fully functional leaves on a mature plant. A minimum of $8-10$ functional leaves are required to allow proper maturation of a bunch (Rieger, 2006). The cord roots are initiated from the corm and they range from 50 to $100 \mathrm{~cm}$ in length; occasionally reaching $3 \mathrm{~m}$ (Blomme \& Ortiz, 2000). In addition to the use of banana fruit pulp for food and income, the use of other plant parts has been reported by Mohapatra et al. (2010). The banana peel is a rich source of starch (3\%), crude protein (6-9\%), crude fat $(4-11 \%)$, essential amino acids and micronutrients (Emaga et al., 2008). In addition, micronutrients ( $\mathrm{Fe}$ and $\mathrm{Zn}$ ) were found in higher concentration in peels compared with the pulp (Davey et al., 2009). The concentration of hydrogen cyanide, an extremely poisonous substance and oxalate contents in banana peels were found to be $1.33 \mathrm{mg} / \mathrm{g}$ and $0.51 \mathrm{mg} / \mathrm{g}$, respectively, falling within safety limits (Anhwange, 2008). Furthermore, banana peel can be used in wastewater treatment (Memon et al., 2008) and as a colour absorbent in water containing textile dyes (Yavuz \& Audin, 2006). Kiichiro et al. (2005) also indicated that banana peel could suppress testosterone-induced prostate gland enlargement. Banana leaves are used extensively for weaving baskets; as mats, table clothes and plates for eating as well as cups for drinking soup; as a food wrapper for marketing and cooking and for covering food (Karamura, 1993). Old leaves are used for wrapping up banana bunches (bunch covers) for protection against bats and birds, and rural people use large leaves of bananas as an umbrella during the rainy season (Kambuou, 2002). As the protein content of green banana leaves is substantial (Oliveira et al., 2007), green banana leaves are hence a good feed for ruminants. Dried banana leaves are used as fuel, and as a substrate to grow mushrooms (Mustaffa and Sathiamoothy, 2002). The floral stalk contains high concentrations of starch (26\%) and can be used in the pharmaceutical and the food industry (Oliveira et al., 2007). In Malaysia and India, the male bud is cooked and consumed as a vegetable (Hassan, 2002). Juice from male buds of banana has been reported as a remedy for stomach problems (Mustaffa \& Sathiamoothy, 2002). Rudiger \& Gabius (2001) reported that lectins found in banana plant tissues, could be effectively used for human consumption. Pseudostems can be recycled for use as a biofertiliser (Phirke et al., 2001). They contain good amounts of cellulose and starch and can thus be used as cattle feed (Katongole et al., 2008). With low amounts of ash and lignin and a high amount of holocellulose, pseudostems and petioles are suitable for pulping in the paper industry (Uma et al., 2005). Furthermore, the pith or the tender core of the banana pseudostem (un-emerged immature leaves) has been used as food after boiling and the addition of spices (Mohapatra et al., 2010). In terms of medicinal properties, the banana pseudostem 
contains pathogenesis-proteins possessing antimicrobial properties (Baree et al., 2000). In addition, banana pseudostem fibre bundles have high specific strength modulus (Lassoudière, 2010); therefore, some automobile companies use this fibre to reinforce the body of the vehicle (Pothan et al., 2005). In addition, banana fibre can be used in handicrafts and textiles.

Abaca (Musa textiles) fibre is used for the production of marine ropes because of its strength, lightness and water-resistance. In addition, high quality paper cardboard, tea bags, banknotes, filter paper and high quality fabric material can be prepared from Musa textilis pseudostem fibre (Afza et al., 1996). The corm is a source of starch and has been eaten in times of famine in Africa and Asia (De Langhe, 1995). Banana roots have been reported to have some coccidiostatic properties (Tafara et al., 2005). Enset (Ensete ventricosum) the close relative of banana is not cultivated for its bunch but its pseudostem and corm. Enset pseudostems and corms are processed into fermented starch that is used for making flatbread or porridge across the highland regions of southwestern Ethiopia. In

\section{MATERIALS AND METHODS}

This study determined the use of the different banana plant parts, other than the fruit pulp, in the North and South Kivu provinces of eastern DR Congo. The study was conducted through surveys targeting farmers in two territories per province, i.e. Beni and Lubero in North Kivu, and Kabare and Walungu in South Kivu in the year 2011. These territories were selected based on Musa production and level of cultivar diversity. In each territory, localities and farms/farmers were randomly sampled.

In North Kivu, the study site selection criteria also considered the two key agro-ecological areas: Lubero (1687 masl) where east African highland bananas (Musa AAA-EA) are mainly cultivated and Beni, located at a lower elevation (1066 masl), where plantains (Musa AAB) predominate. In the Lubero territory of North Kivu, seven localities namely Vusamba, Kasinga, Vusa, Munoli, Muhangi, Mabambi and Musienene were selected, while in the Beni territory, seven localities namely Mayimoya, Oicha, Mangina, Mantumbi, Kyatsaba, Kalau and Isale addition, enset is used as clothing material, roofing material, bedding material, cattle-feed and plates for serving food (Brandt et al., 1997). Corm pieces of immature enset plants are also boiled just like solanum potato and eaten. In addition, enset fibre is extracted from the leaf sheaths during processing. The quality of enset fibre is reported to be similar to that of Musa textilis (Afzaet al., 1996). Moreover, banana plant parts can be used to generate energy through decomposition; and used as good composting material (Oliveira et al., 2007). Baig et al. (2004) indicated that glucose is abundant in most plant parts except in the rachis. The use of the different plant parts is influenced by agro-ecological conditions, cultivars grown, cultural influences and socio-economic factors. This study was carried out to elucidate the specific uses of the different banana plant parts, other than the fruit pulp, in eastern Democratic Republic of Congo. Knowledge generated through this study will be used as a basis for further diversification of the use of the banana plant. The available knowledge on different uses of plant parts in regions other than eastern DR Congo could also be introduced and promoted.

were selected. In South Kivu, six clusters of localities were sampled, namely, Kabamba, Luhihi and Bugorhe in Kabare territory, while Burhale, Lurhala and Ikoma were sampled in Walungu territory. These two territories represent the main east African highland banana growing zones in South Kivu. A total of 100 farmers with at least 50 mats of banana and/or plantain in their fields were randomly sampled per territory giving a total of 200 farmers/farms per province. Data were collected on the use of different banana parts, other than the fruit pulp, using a structured questionnaire. Additional data were captured through visual observations and photography. Data across the study sites were compared using the Statistical Package for Social Scientists (SPSS, 2008) and the Microsoft Excel Software. T-tests (at 95\% confidence Interval) were carried out to compare the different banana uses other than the fruit pulp across the two provinces using SPSS. 


\section{RESULTS}

This study unveiled a wide range of uses for the different banana parts, other than the fruit pulp, in both South and North Kivu. These uses varied according to plant part and study location.

Banana peels: Across the study sites, banana peels were mainly used as feed/forage for domestic animals and to a lesser extent as a source of compost manure for soil fertility management (Fig. 1). The proportion of farmers in North Kivu (75\%) and South Kivu (66\%) who used banana peels as livestock feed was not significantly different $(P \leq 0.05)$. In contrast, banana peel use for compost was significantly higher $(P \leq 0.05)$ in South Kivu (34\%) compared with $27 \%$ in North Kivu.

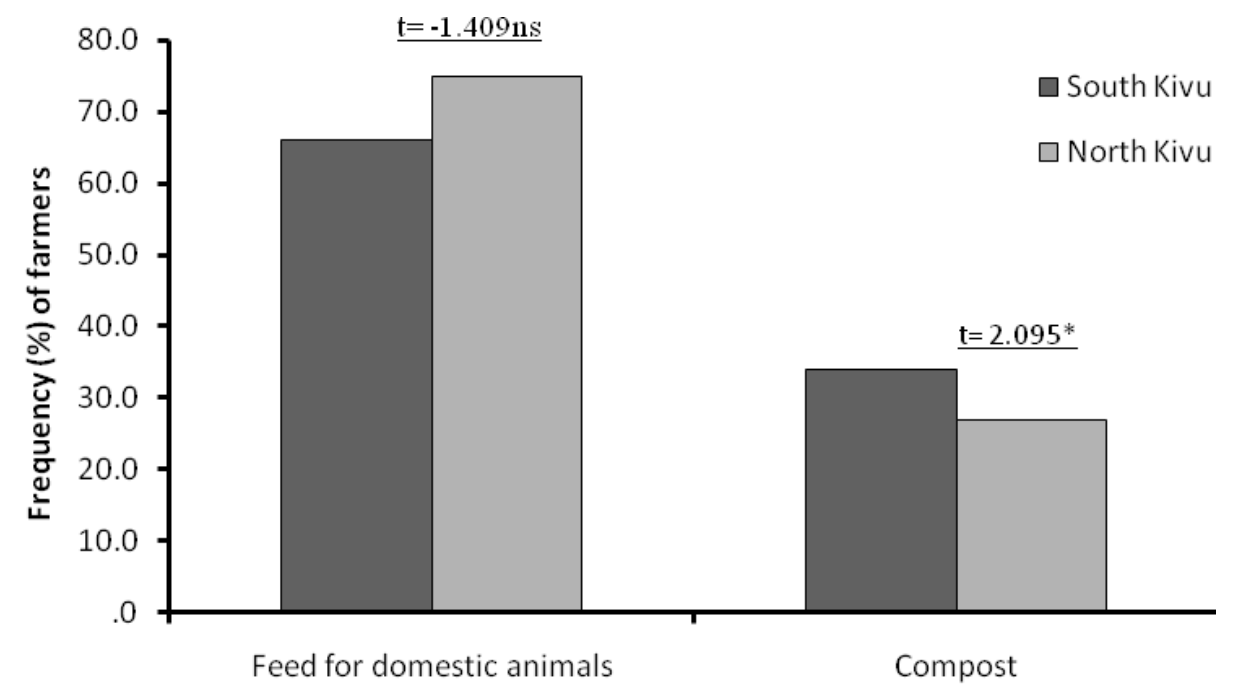

Uses of banana peels

Figure 1: The different uses of the banana peel in South Kivu $(n=200)$ and North Kivu $(n=200)$, provinces of eastern DR Congo in the year 2011. ' $n s^{\prime}$ and "*' denote not significantly and significantly different at $(P \leq 0.05)$, respectively.

Banana male buds: Male buds were mainly used as play items for children across the two provinces. A significantly higher $(P \leq 0.001)$ male bud use for play items was observed in South Kivu (76\% of the respondents) compared with $60 \%$ in North Kivu (Fig. 2). Other uses of the male bud included: source of compost manure, food (vegetable), medicine for humans ( 2 to $4 \%$ ) and forage for livestock (Fig. 2). No significant differences between the provinces were observed $(P \leq 0.05)$ in male bud use for compost manure, human medicine or forage, while a significantly higher $(P \leq 0.001)$ use of male buds for food was observed in North Kivu compared with South Kivu. 

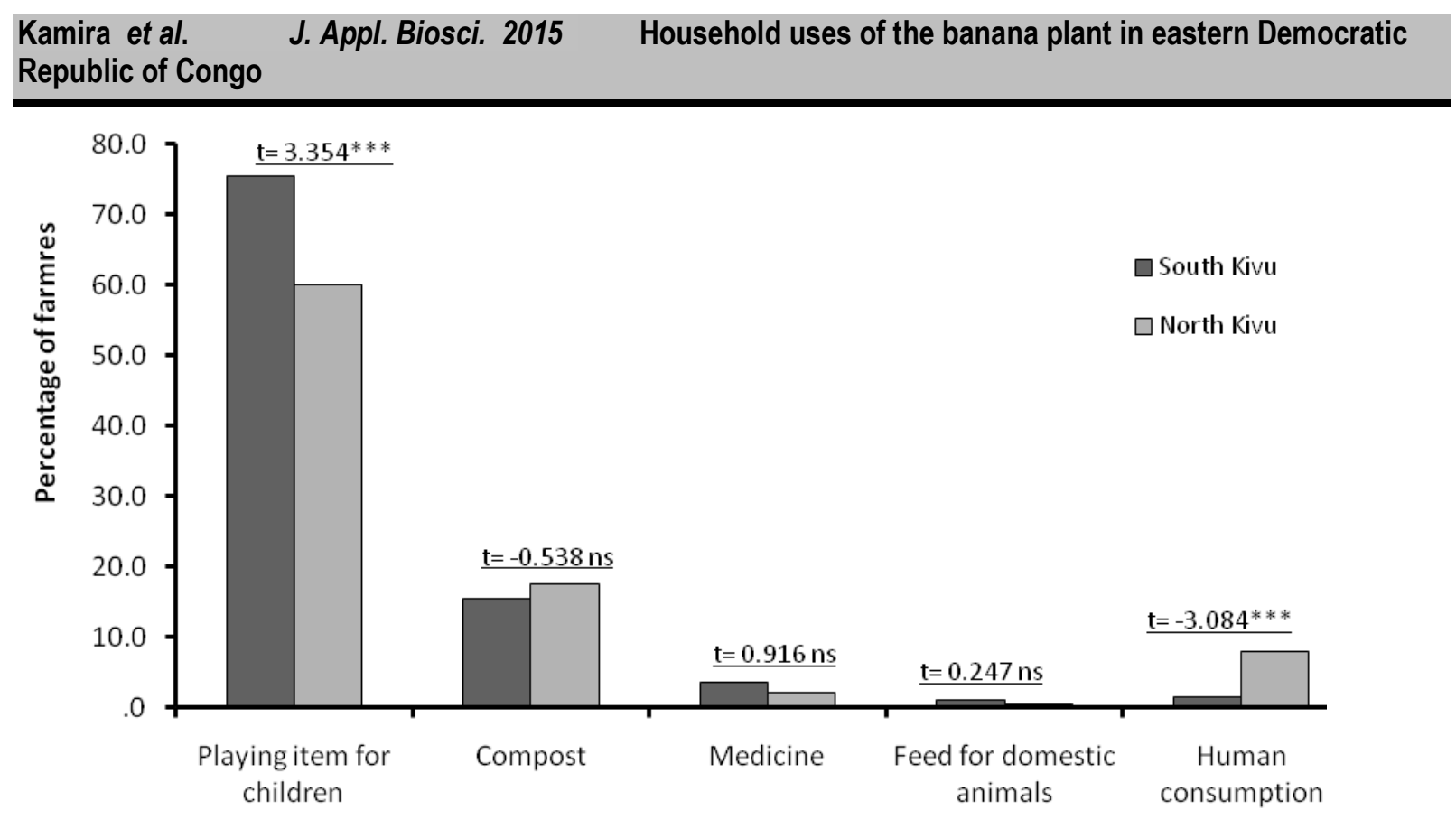

Uses of banana male bud

Figure 2:The different uses of the banana male bud in South Kivu $(n=200)$ and North Kivu $(n=200)$ provinces of eastern DR Congo in the year 2011. ' $n s$ ', and ${ }^{* * *}$ denote not significantly different at $P \leq 0.05$, and significantly different at $P \leq 0.001$, respectively.

Flower stalk (rachis): Across the study sites, the flower stalk had several uses that in order of importance included composting material, play items for children, forage for domestic livestock and fibre extraction. A significantly higher $(P \leq 0.001)$ proportion of the respondents used the rachis as a compost material in South Kivu (i.e. 66\%) compared with 37\% in North Kivu province. In contrast, significantly more respondents ( $\mathrm{P} \leq$
0.001 ) in North Kivu (28\%) used the rachis as play items compared with $8 \%$ in South Kivu. A considerably higher $(P \leq 0.001)$ number of respondents in South Kivu (8\%) use banana rachis to feed livestock compared with a meagre $1 \%$ in North Kivu province. A small percentage of the respondents across the study sites extracted fibres from the banana rachis (Fig. 3 ). 


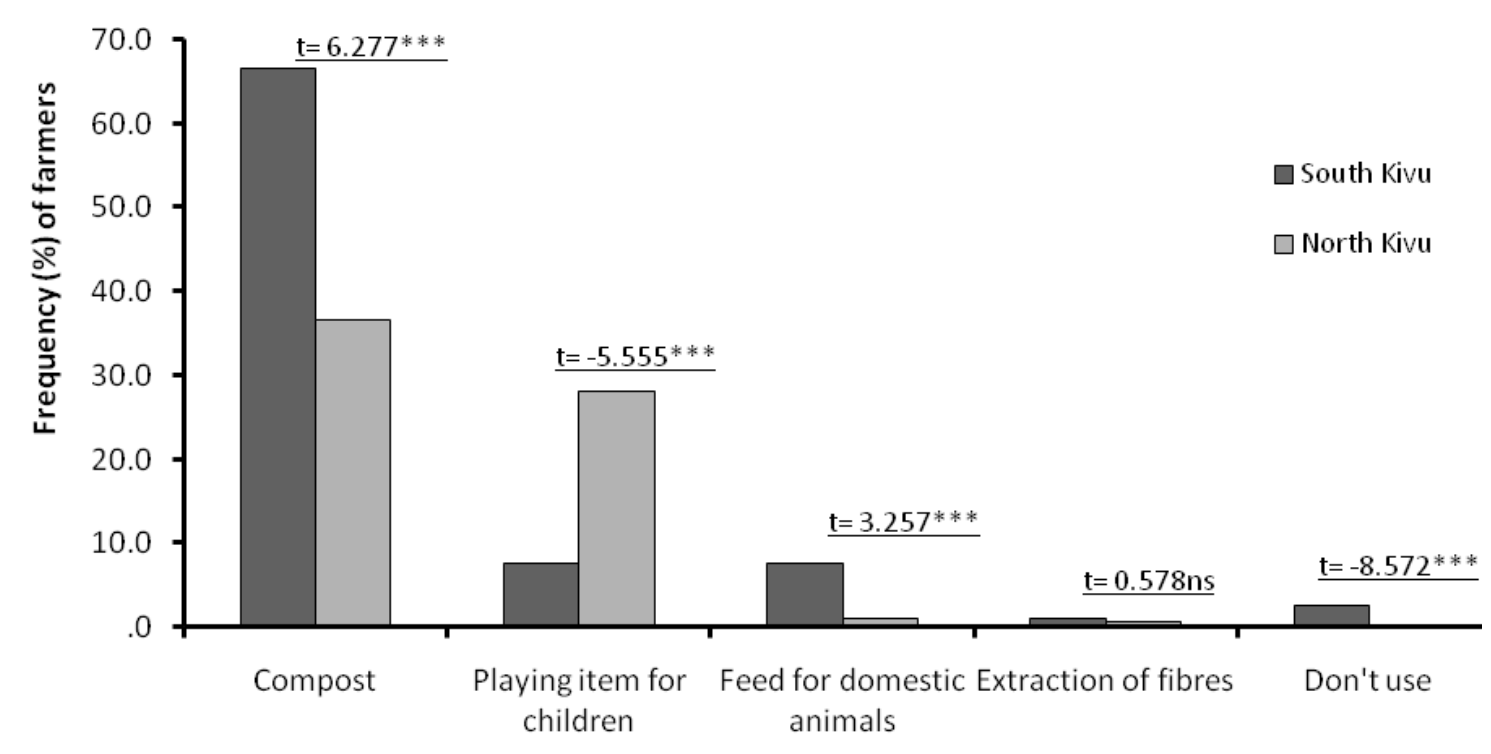

\section{Uses of banana rachis - flower stalk}

Figure 3. The different uses of the banana rachis (flower stalk) as reported by farmers in South Kivu $(n=200)$ and North Kivu $(n=200)$, eastern DR Congo in the year 2011. ' $n s^{\prime}$ and ${ }^{* *}$ denote not significantly different at $P \leq 0.05$ and significantly different at $P \leq 0.001$, respectively.

Fresh banana leaves: Fresh banana leaves had multiple uses across the study region. The main uses reported included feed for livestock and food wrapping (Fig. 4). Significantly more $(P \leq 0.001)$ respondents in South Kivu $(53 \%)$ compared with North Kivu (21\%) were observed to use fresh banana leaves as feed for their domestic animals. In contrast, significantly more $(P \leq 0.001)$ respondents in North Kivu (58\%) were observed to use fresh banana leaves for covering food, especially the East African highland banana while cooking, compared with
$37 \%$ in South Kivu. This practice was reported to give food a good aroma, more taste and flavour. Functional leaves were also reportedly used for covering cassava for fermentation in North Kivu ( $7 \%$ of respondents) while it was not a common practice in south Kivu. Other uses of fresh banana leaves either reported and or observed across the study sites include mulch, bedding material, wrapping materials and cover for fresh vegetables (i.e. to prevent desiccation and increase shelf life) (Fig. 4 and Fig. 8). 

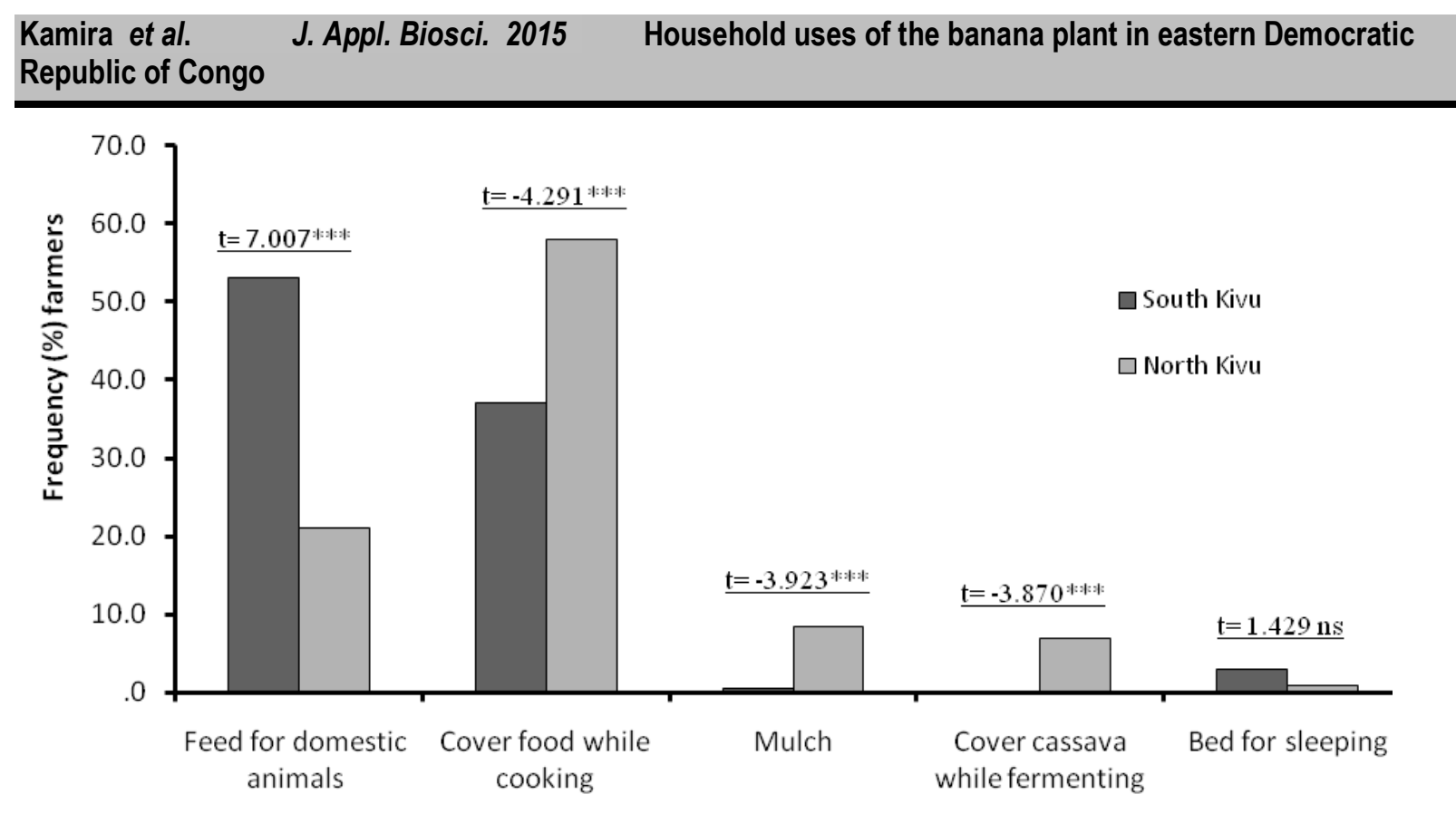

Uses of banana fresh leaves

Figure 4: The different uses of banana fresh leaves in South Kivu $(n=200)$ and North Kivu $(n=200)$, eastern DR Congo in the year 2011. ' $n s^{\prime}$ and ${ }^{* * *}$ denote not significantly different at $P \leq 0.05$ and significantly different at $P \leq 0.001$, respectively.

Dry banana leaves and dry leaf sheaths: Dry banana leaves had a wide range of uses that included mulching of plantations, use as ropes, bedding material, construction material, compost, art and crafts. Significantly, higher $(P \leq 0.001)$ numbers of respondents were observed to use dry banana leaves and sheaths for mulching (55\% of farmers), ropes (32\%) and construction $(13 \%)$ in South Kivu compared with $38 \%, 30 \%$ and $0 \%$ in North Kivu, respectively (Fig. 5). The use of dry banana leaves and leaf sheath for construction was mainly limited to roofing and or walling kitchens, toilets, bathing and temporary shelters. Though this practice was not mentioned in North Kivu, field observations and photos clearly showed that there it is also a common practice (Fig. 8). A significantly high $(P \leq 0.001)$ percentage of people in North Kivu (45\%) also used dry leaves as bedding materials, a practice that was lacking in South Kivu. The use of dry leaf sheaths and leaves for the production of art works and crafts was not common across either province (Fig. 5). Other uses of dry leaves/ sheaths observed in the study region included: use as a substrate for mushroom production; cover material while fermenting cassava, cover material while extracting sap from palm trees for subsequent palm wine production and ripening of bananas; and chicken laying nests (Fig. 8). 


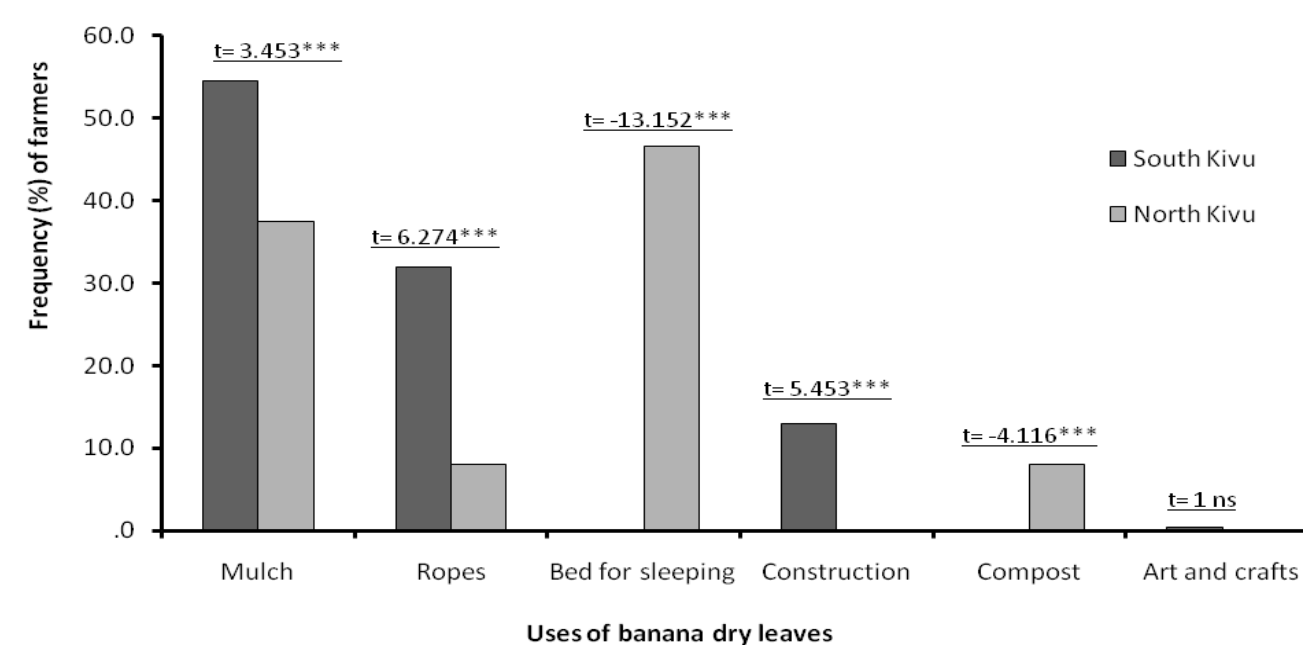

Figure 5: The uses of dry banana leaves in South Kivu $(n=200)$ and North Kivu $(n=200)$, eastern DR Congo in the year 2011. ' $n s^{\prime}$ and ${ }^{* * *}$ denote not significantly different at $P \leq 0.05$ and significantly different at $P \leq 0.001$, respectively.

Banana pseudostem: The banana pseudostem had a variety of uses in both North and South Kivu. In the south Kivu region, banana pseudostems mainly provided ropes for tethering domestic animals ( $59 \%$ of farmers); while in North Kivu, it was mostly used as a play item for children $(55 \%)$ (Fig. 6). A small fraction of the respondents reportedly used the banana pseudostem as a source of medicine, feed for livestock, compost and mulch. Though few respondents reported the use of pseudostems as mulch and compost, field observations across most farms showed whole or cut pseudostems lying within the banana plantations. This practice though done unconsciously helps to recycle nutrients within the fields. Other uses observed in the course of this study-included rope making for roofing, bags, mats, artwork and crafts.

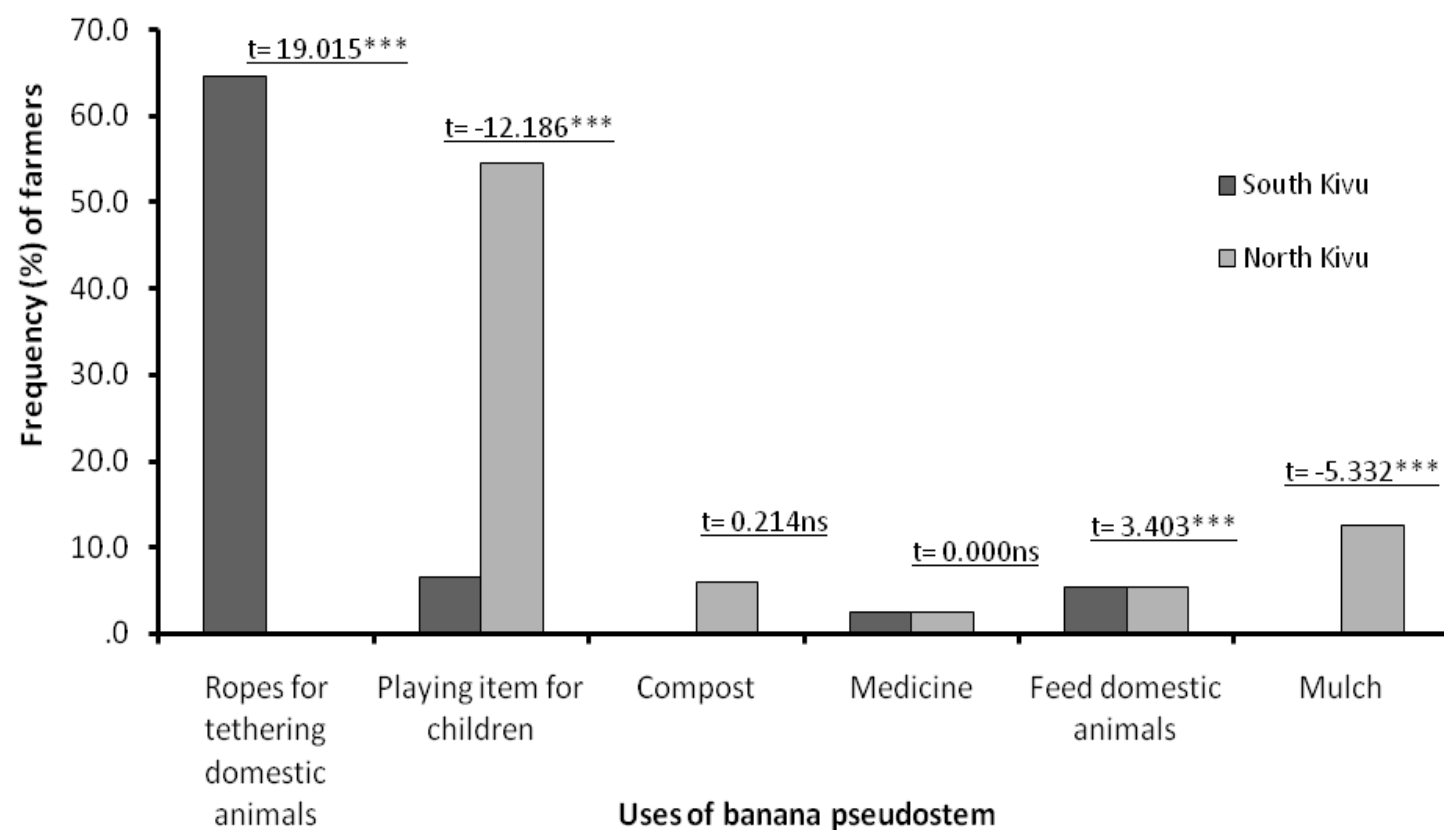

Figure 6: Uses of the banana pseudostem in South Kivu $(n=200)$ and North Kivu $(n=200)$, eastern DR Congo in the year 2011. ' $n s^{\prime}$ and ${ }^{* * *}$ denote not significantly different at $P \leq 0.05$ and significantly different at $P \leq 0.001$, respectively. 
Banana corms: In the South Kivu province, almost all the farmers $(97 \%)$ had no use for the banana corms (rhizome), though in North Kivu, most of farmers use banana corms as cooking stands (instead of stones) (Fig.
7). Few farmers in the North Kivu region also used the banana corms to feed domestic animals. Other reported uses of the corm included compost manure and play materials for children.

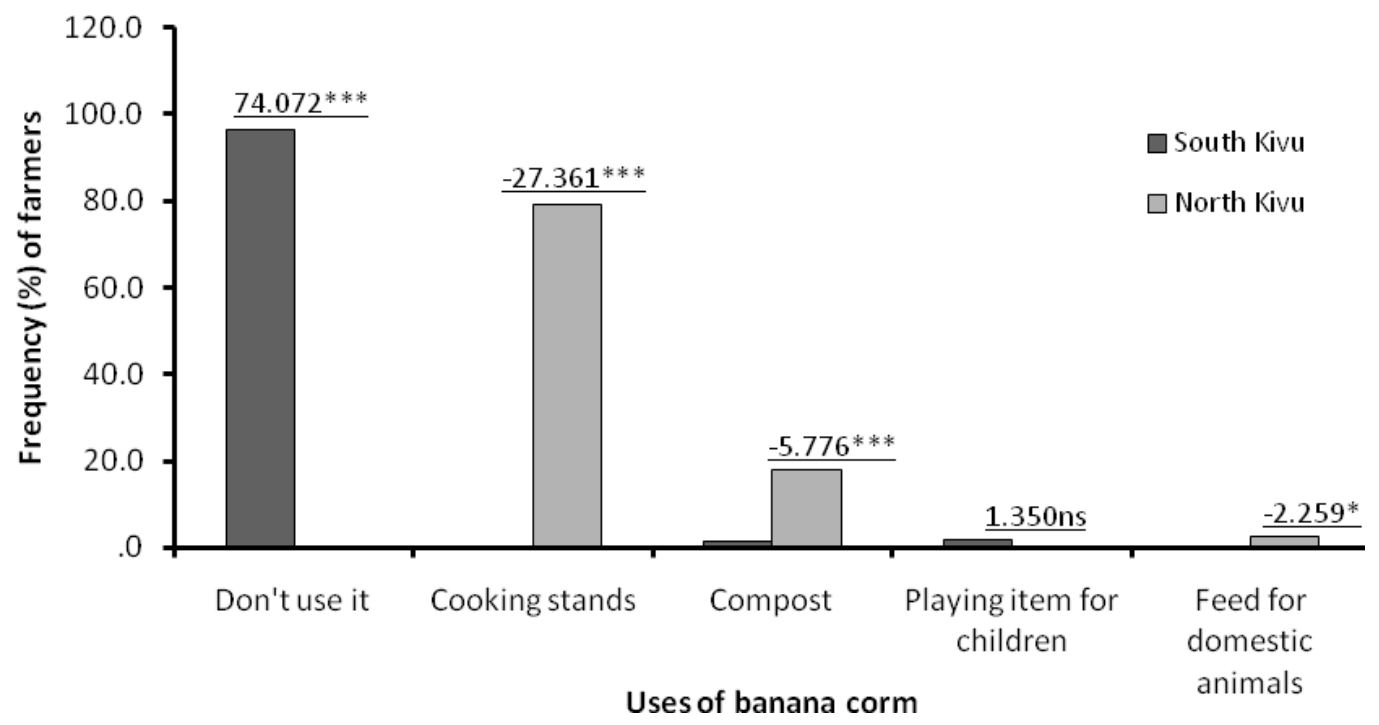

Figure 7: Uses of the banana corms (rhizome) in South Kivu $(n=200)$ and North Kivu $(n=200)$, eastern DR Congo in the year 2011. 'ns', '*' and *** denote not significantly different at $P \leq 0.05$, significantly different at $P \leq 0.01$ and significantly different at $P \leq 0.001$, respectively. 


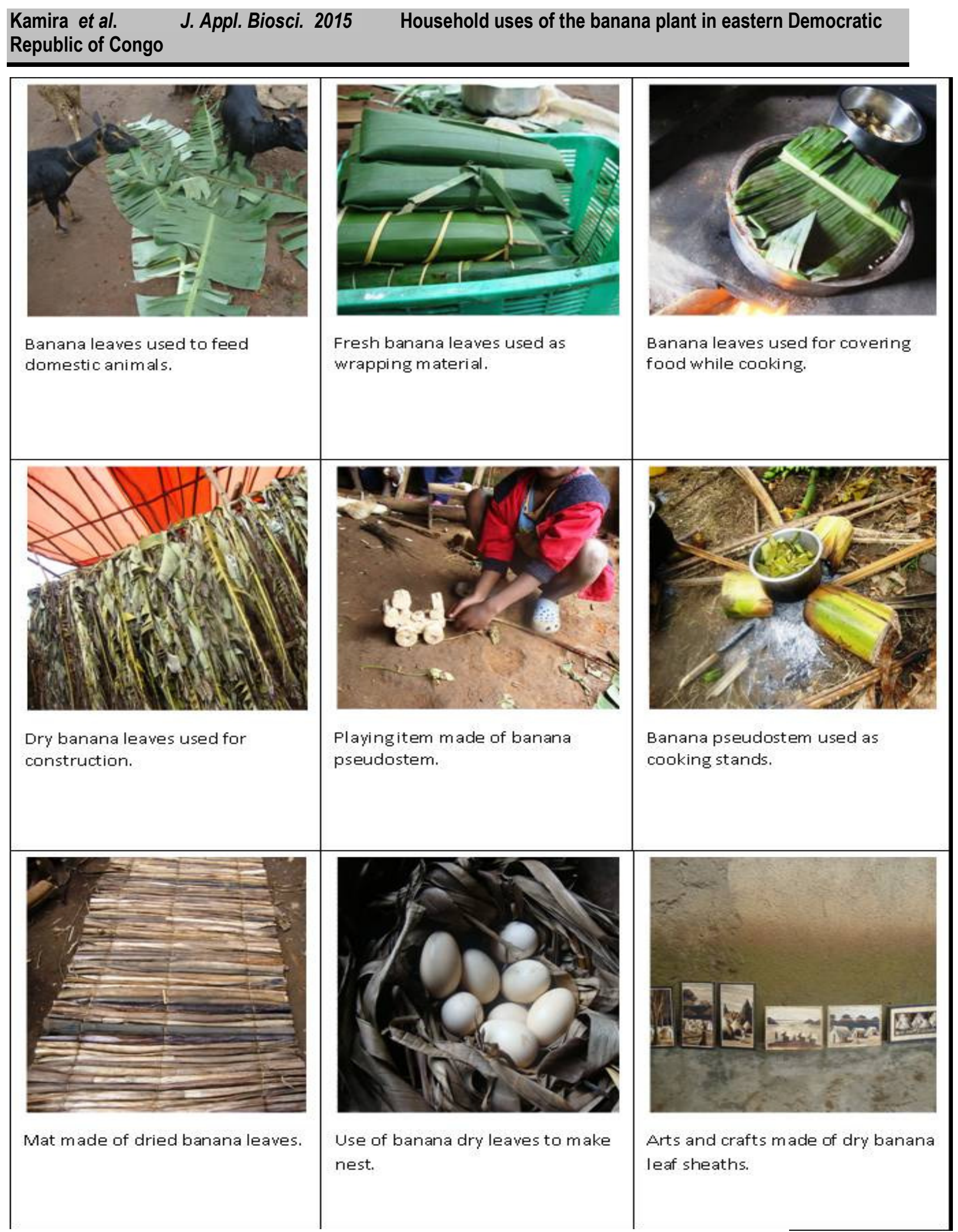

Figure 8: Photos showing some of the reported and observed uses of the banana plant other than the banana fruit pulp in eastern DR Congo in the year 2011. 


\section{DISCUSSION}

This study documented the different uses of banana plant parts other than the fruit pulp, in the North and South Kivu provinces of eastern DR Congo. The different banana parts assessed included the banana peels, male buds, flower stalk (rachis), the fresh banana leaves, the dry banana leaves and leaf sheath, the banana pseudostem and the corm. All the above plant parts were observed to be variably useful to the communities in the North and South Kivu provinces of eastern DR Congo, with noticeable variations between the two provinces. For example, the corm compared with the other plant parts examined above was least useful to the communities. Banana peels were mainly used as feed/forage for domestic animals and to a lesser extent as a source of compost manure for soil fertility management. The banana peels are rich in starch (3\%), crude protein (6$9 \%$ ), essential amino acids (leucine, valine, phenylalamine and threonine), crude fat (4-11\%) and high dietary fibre (50\% of fresh weight) (Emaga, 2007; Wathelet et al., 2007; Emaga et al., 2008) and therefore a good source of animal feed. The banana peel is also rich in minerals, particularly potassium, phosphorus, calcium and magnesium (Emaga et al., 2008). Banana is a heavy feeder of potassium and requires nearly $1500 \mathrm{~kg}$ of $\mathrm{K}$ per hectare during a crop cycle (Ganeshamurthy et al., 2011). Recycling of composted banana peels in banana plantations in the study region therefore helps to recycle minerals, especially potassium that is needed in large quantities by banana plants. Banana male buds were mainly used as play items by children. For example, male buds were often used as baby toys by girls and car toys by boys. The high use of male buds for playing could be attributed to the fact that little or no cultural value is placed on having play items for children in this region. This may be further compounded by low incomes that do not allow parents to allocate resources to play items. More still, there are no other competing uses for the male bud in these provinces. Other uses of the male bud included: source of compost manure, food (vegetable) and medicine for humans and forage for livestock (Fig.1). In Southeast Asia, banana flowers and male buds are often eaten cooked or raw and are used to feed pigs (Hassan, 2002). In Uganda, male buds are often fed to cattle and are believed to increase milk production (Deborah Karamura, personal communication, 2012). Medicinal properties of the male bud have also been reported. For example, Loganayaki et al. (2010) recommended the use of banana flower extracts to make health supplements due to its antioxidant potential.
Similarly, Bagavan et al. (2011) reported that ethanolbased extracts of banana flowers inhibited the growth of pathogenic bacteria such as Bacillus subtalis, Bacillus cereus and Escherichia coli in the laboratory and may help heal wounds and prevent infections. It has been estimated by the World Health Organization that $80 \%$ of the developing world's population meets its primary healthcare needs through traditional medicines. For instance, in China, about 1 billion people, both in urban and rural areas, depend largely on plant-based medicinal aids while 800 million inhabitants of South Asia rely on herbal medicines (Bizimana, 1997). The flower stalk (rachis) was mainly chopped in the field as either compost or mulch material across the study region. This practice is important for minimizing the mining of nutrients and sustaining the fertility of the soils. A significant fraction of the respondents reported the use of the rachis as play items. Children convert the pseudostem into different shapes such as vehicles and boats that are used for playing. This practice is important since little/no value and therefore costs are placed on play items in these communities. A small percentage of the respondents across the study sites extracted fibre from the banana rachis. Banana fibre has good morphological characteristics and good mechanical strength (Venkatesha, 2013). A study to explore the extraction procedures, quantity and quality of the extracted fibre from banana rachis is worth pursuing. Banana leaves were used either fresh or dry. Fresh banana leaves were mainly used as feed for livestock and food wrapping material. High population densities and small landholdings characterize these study sites; as such, there are no grazing fields in these farming systems. Therefore, zero grazing is practiced by households that have the financial means to acquire livestock. In Tanzania, Kimambo \& Muya (2011) determined that banana leaves provide sufficient nutritional value to be a highly valuable food for dairy cows and cattle. The use of leaves for covering food while cooking ('Matoke'), reportedly gives food a good aroma, more taste and flavour. Likewise, this is a common culinary practice in banana growing and consuming communities in Uganda (Karamura, 1993). Dry banana leaves and dry leaf sheaths were mainly used for mulching of plantations in both South Kivu and North Kivu. Dry banana leaves and leaf sheaths use as mulch and compost supplies a large quantities of nutrients. For example, Robinson and Hogwood (1965) reported that annual application of dried banana leaves as mulch (at $25 \mathrm{t} / \mathrm{ha}$ ) replaced the 
nutrients removed at harvest and even provided additional nutrients. As previously reported by van Asten et al. (2004), dry banana leaves could therefore make a valuable input in the management of soil fertility over the study regions. In addition, dry banana leaves were used for the construction of roofs and or walls, especially for kitchens, toilets, bathing and temporary shelters. This can be attributed to the fact that dry banana leaves and leaf sheaths are cheap and easily accessible by all households. Likewise, in Uganda, dried leaf sheaths are extensively used as roofing material for houses (Karamura, 1993). A high percentage of people in North Kivu $(45 \%)$ also used dry leaves as bedding materials in place of mattresses. It is important to note that this region has a long experience of conflict characterized by population migrations, property loss and high poverty levels. Therefore, several households cannot afford expensive bedding and they rely on available alternatives for bedding. The use of dry leaf sheaths and leaves for the production of art works and crafts was not common. This could be attributed to a lack of art skills and markets. Commonly known culinary attributes of dry leaves such as the use of ash obtained from burning dry banana leaves for flavouring curries or as a salt substitute in India (Nelson et al., 2006) were not observed or recorded across the study regions. The banana pseudostem was significantly used for ropes for tethering small ruminants and construction in South Kivu. In Uganda, pseudostems are also used to weave ropes for tethering goats and sheep (Karamura, 1993). Similar to the male buds and the flower stalks, the pseudostem was an important play item for children in North Kivu. A small fraction also used

\section{CONCLUSION AND RECOMMENDATIONS}

This study documents a wide range of uses for the different parts of the banana plant other than the fruit pulp in both North and South Kivu. Noticeable variations in the use of plant parts were seen between the two provinces. For example, in South Kivu, over $96 \%$ of the farmers had no use for the corms whereas all the farmers in North Kivu reported at least one use for the corm. The most prevalent uses across plant parts noted included use for mulch and compost, feed for livestock, construction materials, ropes for tethering small ruminants and play items for children. Other uses included extraction of fibre, arts and crafts and use as medicine. Culinary and medicinal attributes, use for art and crafts however, were the pseudostem as a source of medicine in both South and North Kivu. In India, village physicians use the extracts of banana pseudostem pith to treat persons bitten by poisonous snakes (Pushpangadan, 1989). Pseudostem use for forage was limited though Kimambo \& Muya (2011) reported a higher digestibility for the banana pseudostem (75\%) than the leaves $(65 \%)$. Banana pseudostem use for human consumption was not observed in this study though there is a registered patent that describes a process to use the (heart) of the banana pseudostem (young unfolded leaf/shoot) for human consumption (Cardoso, 2007). Pseudostem use as mulch and compost was also common though unconsciously practiced. This practice helps to recycle nutrients within the fields. Banana pseudostems have been reported to be rich in essential minerals, mainly containing high concentrations of potassium (Wall, 2006; Oliveira et al. 2007). The banana corms were mainly of importance in North Kivu, with a high percentage of households using corms as cooking stands. Few farmers in the North Kivu also used corms to feed domestic animals. The use of banana corms for medicinal and culinary purposes has however been reported in Asia. For example, rhizome extracts to which a little common salt is added could cure pyorrhoea and heal loosened gums. Some villagers in India use the extract of the banana rhizome to treat food poisoning and the powder of the dried banana rhizome and root to treat diabetes (Pushpangadan et al., 1989). De Langhe (1995) also reported that the banana corm is a source of starch and has been eaten in times of famine in Africa and Asia.

less reported in this study and yet could be of great benefit to resource constrained communities. We recommend in-depth studies especially to verify and understand the culinary and medicinal attributes reported for the different plant parts in the region. Use of the male bud as a vegetable has been proven and could be promoted among communities in the region. The nutrient values in the pseudostem are high and its promotion as animal feed in this highly populated region with small land holdings could enable zero grazing of small ruminants. This study could also be a pre-cursor for further studies that could promote banana use diversification in this region. 


\section{ACKNOWLGEMENTS}

This study was carried out in the overall framework of the CGIAR research program on Roots, Tubers and Bananas. The Belgian Directorate General for Development that funded this study is gratefully acknowledged. In addition, the Université Catholique du Graben in North Kivu, and the Université Catholique de

\section{REFERENCES}

Afza R, van Dure M, Morpurgo R, 1996. Regeneration of Ensete ventricosum through somatic embryogenesis and adventitious buds. Plant Cell Reports 15: 445-448.

Anhwange BA, 2008. Chemical composition of Musa sapientum (banana) peels, Journal of Food Technology 6: 263-268.

Bagavan A, Rahuman AA, Kaushik NK, Sahal D, 2011. In vitro antimalarial activity of medical plant extracts against Plasmodium falciparum. Parasitology Research 108: 15-22.

Baig MMV, Baig MLB, Baig MIA, Yasmeen M, 2004. Scarification of banana agro - waste by cellulolytic enzymes. African Journal Biotechnology 3: 447-450.

Bakelana BK, Vangu P, Mputu KK, 2000. Results of a survey on banana conduced among farmers in the Democratic Republic of Congo. InfoMusa 9 (1): 22-23.

Baree A, Peumans WJ, Menu - Bouaouiche L, Van damme EJK, May GD, Herrera AF, Leuven FV, Rouge $P, 2000$. Purification and structure analysis of an abundant thaumatin - like protein from ripe banana fruit. Planta 211: 791-799.

Bizimana N, 1997. Scientific evidence of efficacy of medicinal plants for animal treatment. Ethnoveterinary Medicine: Alternatives for Livestock Development: Pune, India, Proceedings of an International Conference 2: 11-12.

Blomme G, Ortiz R, 2000. Preliminary assessment of root systems morphology in Musa. In: Craenen, K., Ortiz, R., Karamura, E.B., \& Vuylsteke (Eds.) Proceedings of the International Conference on Banana and Plantain for Africa. Acta Horticulturae 540: 259-266.

Brandt SA, Spring A, Hiebisch C, McCabe JM, Tabogie E, Diro M, Wolde-Michael G, Yantiso G, Shigeta M, Tesfaye S, 1997. The tree against hunger. Enset-based agricultural systems in Ethiopia. American Association for the Advancement of
Bukavu, DR Congo are acknowledged for their crucial role in data collection. The authors also gratefully acknowledge the farmers of the surveyed localities across the provinces who willingly provided the information used in this study. Thanks to David Turner (University of Western Australia) for editing this manuscript.

Science with the Awassa Agricultural Research Centre, Kyoto University for African studies and University of Florida, Washington.

Cardoso MH, 2007. Coração De Bananeira EmConserva: Processamento e Produto. Patent n\# PI0506651-4. http://www. patentesonline.com.br.

Davey MW, Van - den Berg I, Markham R, Swennen R, Keulemans J, 2009. Genetic variability in Musa fruit provitamin A carotenoids, lutein and mineral micronutrients, Food Chemistry 115: 806-813.

De Langhe E, 1995. Banana and plantain: the Earliest Fruit Crops? International Network for Improving of banana and Plantain, Montpellier, France, available online at http://bananas.bioversityinternational.org/files/fil es/pdf/publications/ar95_en.pdf.

Emaga TH, 2007. Effects of the Stage of Maturation and Varieties on the Chemical Composition of Banana and Plantain Peels. Food Chemistry 103: 590-600.

Emaga TH, Robert C, Ronkart SN, Wathelet B, Paquot $\mathrm{M}, 2008$. Dietary fibre components and pectin chemical features of peels during ripening in banana and plantain varieties. Bioresource Technology 99: 4346-4354.

Ganeshamurthy AN, Satisha GC, Prakash P, 2011. Potassium nutrition on yield and quality of fruit crops with special emphasis on banana and grapes. Indian Institute of Horticultural Research, Hessaraghatta Lake Post, India. Karnataka Journal; of Agricultural Sciences 24: $29-38$.

Hassan MN, 2002. Banana industry and R\&D in Malaysia, Advancing banana and plantain R\&D in Asia and the pacific, in Proc 1st BAPNET steering committee Meeting (BAPNET, Los Banos, Laguna, Philippines).

Kambuou RN, 2002. Status of banana R \& D, production and consumption in Papua New Guinea, report published in advancing banana and plantain R \& 
$D$ in Asia and the Pacific, in Proc $1^{\text {st }}$ BAPNET steering committee Meeting (BAPNET, Los Banos, Laguna, Philippines). Pp. 125-138.

Karamura EB, 1993. The strategic importance of bananas and plantains in Uganda. In: Gold, C.S. and Gemmil, B (eds). Proceedings of a research co-ordination meeting for biological and integrated control of highland banana and plantain pests and diseases. Cotonou, IITACotonou, Benin. Pp 384-397

Katongole CB, Bareeba FB, Sabiiti EN and Ledin I, 2008. Nutritional characterization of some tropical urban market crops wastes. Animal Feed Science and Technology 142: 275-291.

Kiichiro A, Tomoyuki K, Kazunaga Y, 2005. Banana peel extract suppressed prostate gland enlargement in testosterone-treated mice. Dermatologic Surgery 7: 855-60.

Kimambo AE, Muya HMH, 2011. Rumen degradation of dry matter and organic matter of different parts of the banana plant. Livestock Research for Rural Development. 3: 35-40.

Lassoudière A, 2010. History of Banana. Quire. Pp. 351.

Loganayaki N, Rajendrakumaran D, Manian M (2010). Antioxidant capacity and phenolic content of different solvent extracts from banana (Musa parasidiaca) and mustai (Rivea hypocateriformis). Food Science and Biotechnology 19: 1251-1258.

Memon JR, Memon SQ, Bhangar Ml, Memon GZ, ElTurki A, Allen GC, 2008. Characterization of banana peel by scanning electron microscopy and FT - IR and its use for Cadmium removal. Colloids and Surfaces B: Biointerfaces 66: 260265.

Ministry of Agriculture of DR Congo, 2002. Annual Report, 2002.

Mohapatra D, Mishra S, Sutar N, 2010. Banana and its by product utilization: An overview. Journal of Science and Industrial Research 69: 323-329.

Mustaffa MM, Sathiamoothy S, 2002. Status of banana industry in India, report published in Advancing banana and plantain $R$ \& $D$ in Asia and the Pacific, in Proc $1{ }^{\text {st }}$ BAPNET Steering Committee (BAPNET, Los Banos, Laguna, Philippines). Pp. 81-92.

Nelson SC, Ploetz RC, Kepler AK, 2006. Musa species (bananas and plantains). In: CR Elevitch, ed. Species Profiles for Pacific Island Agroforestry. Permanent Agricultural Resources, Holualoa,
Hawaii, available online at http://www. agroforestry.net/tti/Musa-bananaplantain.pdf.

Oliveira L, Cardeiro N, Evtunguin DV, Torres IC Silvestre AJD, 2007. Chemical composition of different morphological parts from "Dwarf Cavendish" banana plant and their potential as a non wood renewable source of natural products. Industrial Crops and Products 26: 163-172.

Phirke NV, Patil RP, Chincholkar SB Kothari RM (2001). Recycling of banana pseudostem waste for economical production of quality banana. Ressour Conserv Recycl 31: 347-353.

Pillay M. and. Tripathi L, 2007. Banana. Chapter 15. In: Kole C, ed. Genome Mapping and Molecular Breeding in Plants. Springer-Verlag, Berlin. Fruits and Nuts 4: 281-301.

Pothan LA, Potschke P, Habler P, 2005. The static and Dynamic Mechanical Properties of Banana and Glass Fiber Woven Fabric-Reinforced Polyester Composite. Journal of Composite Materials 39: 1007-1025.

PTRI, 2005. Banana. Development of the Technology on Processing Banana Fibres as an Investment Opportunity. Indigenous Fibres for Textile Application. Textile Development (4). Philippines Textile Research Institute.

Pushpangadan P, Kaur J, Sharma J, 1989. Plantain or edible banana (Musa $x$ paradisica var sapiemtum) some lesser-known folk uses in India. Ancient Science of Life 9: 20-24.

Rieger M, 2006. Banana and plantain - Musa spp. http://www.uga.edu/fruit/banana.html.

Robinson JBD. and Hogwood PH, 1965. Effects of organic mulch on fertility of a lactosolic coffee soil in Kenya. Empire Journal of Experimental Agriculture 1: 67-80.

Robinson JC. and Galan V. 2010. Bananas and Plantains, $2^{\text {nd }}$ edition. Crop Production Science in Horticulture Series 19. CAB International Wallingford, UK.

Rudiger H. and Gabius HJ, 2001. Plant lectins: Occurrence, biochemistry, functions and applications. Glycoconjugate Journal 18: 589613.

Smales LR, 2006. A new acuariid species (Spirurida, Acuariidae) and other nematodes from Hydromys (Muridae, Hydromyinae) from Papua, Indonesia and Papua New Guinea. Zootaxa 11: 27-37. 
SPSS, 2008. Statistical Package for Social Scientists. www.spss.com

Tafara M, Mupangwa JF, Emily FK, 2005. The Efficacy of Banana Plant (Musa paradisiaca) as a Coccidiostat in Rabbits. International Journal of Applied Research Veterinary Medicine 3: 326331.

Uma S, Kalpana S, Sathiamoorthy S, Kumar V, 2005. Evaluation of commercial cultivars of banana (Musa spp.) for their suitability for the fibre industry. Plant Genetic Resources Newsletter 142: 29-35.

van Asten PJA, Gold CS, Okech SH, Gaidashova SV, Tushemereirwe WK, De Waele D, 2004. Soil quality problems in East African banana systems and their relation with other yield loss factors. InfoMusa 13(2): 20-25.

Vangu PG, 2005. Action du vetiver (Vetiveria zizanioides) dans la protection du bananier (Musa sp.) contre les attaques des nematodes des racines. Mémoire, in edit, UNIKIN/ R.D.Congo.

Venkatesha GP. and Venkata KS, 2013. Modification, flexural, impact, compressive properties and chemical resistance of natural fibres reinforced blend composites. Malaysian Polymer Journal 8: 38-44. Available online at: www.cheme.utm.my/mpj.

Wall MM, 2006. Ascorbic Acid, Vitamin A, and Mineral Composition of Banana (Musa sp.) and Papaya (Carica Papaya) Cultivars Grown in Hawaii. Journal of Food Composition and Analysis 19: 434-445.

Wathelet B, Tchango JT, Paquot M, 2007. Effects of the stage of maturation and varieties on the chemical composition of banana and plantain peels. Food Chemistry 103: 590-600.

Yavuz O. and Audin AH, 2006. Removal of direct dyes from aqueous solution using various adsorbents. Polish Studies 15: 155-161. 